\title{
PERAN ACCOUNT OFFICER DALAM MANAJEMEN PEMBIAYAAN DI BANK PEMBIAYAAN RAKYAT SYARIAH DAYA ARTHA MENTARI PANDAAN
}

\author{
Nur Lailatus Sya'adah, Aslikhah \\ lailasaadah214@gmail.com dan aslikhah@yudharta.ac.id \\ Universitas Yudharta Pasuruan
}

\begin{abstract}
In the current era of globalization era, more and more Islamic financial institutions are experiencing very rapid development, especially among Muslim and non-Muslim communities. In Islamic banking, there are various kinds of financial institutions including sharia commercial banks, sharia business units, and BPRS . One of the financial institutions that we will examine is PT. Bank Syariah Daya Artha Mentari Pandaan, which is an Islamic financial institution that is Islamic in nature and is in line with its mission to mobilize funds so that it can be reached by the lower and middle classes to develop employment opportunities, organize funds so that they can grow and develop well in people's lives and state development. BPRS Daya Artha Mentari Branch Pandaan has a variety of products, especially in terms of financing (lending) and funding (funding).In carrying out a financing of PT. BPRS Daya Artha Mentari Pandaan is carried out by an Account Officer who plays a role in managing financing, namely from the beginning of the submission of funds, disbursement, supervision and settlement of financing. And in a financial institution there is usually a financing that has problems both low and heavy levels. The purpose of this study was to determine the role of Account Officer in financing management at the BPRS Daya Artha Mentari Pandaan. Data collection in this study using observation, interviews and documentation. The location of the research was carried out at PT. BPRS Daya Artha Mentari Pandaan, concluded that the role of an Account Officer in financing management is to carry out the financing process that occurs at PT. BPRS Daya Artha Mentari Pandaan starts from submission, completes financing memo, submits complete requirements (in the form of BPKB guarantee, photocopy of BPKB guarantee, copy of KK, photocopy of marriage certificate, photocopy of STNK, photocopy of SHM certificate) then survey by Account Officer, submitted to the Director, and the last is disbursement. And the Account Officer strategy to overcome the risk of problematic
\end{abstract}


financing is to do rescheduling, give summons when the customer has not paid installments for 3 months, the summons will be given up to the next 3 months and make collateral withdrawals as stated in the contract.

Keywords: Account Officer, Financing Management.

\section{PENDAHULUAN}

Bank Perkreditan Rakyat Syariah Daya Artha Mentari Cabang Pandaan merupakan salah satu lembaga keuangan alternatif yang bernafaskan Islam yang sesuai dengan misinya memobilisasi dana sehingga bisa dijangkau oleh masyarakat lapisan bawah dan menengah guna mengembangkan kesempatan kerja, menata usahakan dana sehingga dapat tumbuh dan berkembang guna memenuhi kebutuhan modal kerja anggota nasabah maupun calon nasabah, mempertinggi kualitas SDM nasabah untuk menjadi professional dan Islami, serta menjalin hubungan ukhuwah Islamiyah sesama umat Islam dan berupaya meningkatkan kesejahteraan dan mewujudkan masyarakat dalam perekonomian yang maju, adil, dan makmur.

Bank Pembiayaan Rakyat Syariah Daya Artha Mentari sudah memiliki banyak kantor kas yang tersebar terutama di kabupaten Pasuruan. Perkembangan BPRS Daya Artha Mentari sangat pesat. Hal ini dapat dilihat dari jumlah aset yang dimiliki BPRS Daya Artha Mentari sangat tinggi. Salah satu kantor kas yang kami teliti adalah di BPRS Daya Artha Mentari Pandaan tepatnya di Jl. Pahlawan Sunaryo Pandaan.

Dewasa ini, persaingan antar bank syariah semakin ketat, secara langsung maupun tidak langsung hal ini akan berpengaruh terhadap profitabilitas perbankan syariah. Meskipun tujuan dari bank syariah itu bukan hanya sekedar mencari keuntungan, namun kemampuan bank syariah dalam upaya memperoleh keuntungan menjadi indikator penting untuk keberlangsungan bank syariah serta untuk mengukur kemampuan bersaing dalam jangka panjang. Dalam setiap kegiatannya baik penghimpunan dana maupun pembiayaan, tujuan utamanya adalah untuk memperoleh pendapatan yang semaksimal mungkin. Sebagai upaya memperoleh pendapatan tersebut, aktivitas di BPRS juga menganut azas syari'ah, yakni dengan prinsip bagi hasil, keuntungan maupun jasa manajemen. Dalam pengelolaan dana, manajemen BPRS harus memperhatikan tiga aspek penting dalam mengelola dananya yakni: amanah, lancar dan menguntungkan. BPRS memiliki 
berbagai macam produk terutama dalam hal pembiayaan (lending) dan pendanaan (funding). Dalam pembiayaan, bagi hasil resiko untung dan rugi ditanggung bersama maka dituntut dari pejabat bank yang disebut Account Officer dan komite pembiayaan untuk lebih selektif dan hati-hati dalam menganalisa suatu proyek atau usaha yang diajukan sebelum memberikan keputusan diterima suatu usulan tersebut. Pada dasarnya seorang Account Officer merupakan ujung tombak bank dalam memasarkan produknya, maka seorang Account Officer harus memiliki kecakapan berbicara yang memadai untuk memasarkan produk yang ditawarkan. Disamping itu peranan dan fungsi seorang Account Officer adalah melakukan pemantauan atas pembiayaan yang diberikan kepada nasabah agar nasabah tersebut memenuhi komitmen atas pembiayaannya. ${ }^{1}$

Dalam pemberian kebijakan pembiayaan berdasarkan prinsip syariah dilakukan dengan lost and profit sharing (bagi hasil). Dalam pemberian pembiayaan, seringkali terdapat masalah-masalah dalam pemberian pembiayaan tersebut, seperti adanya kredit macet atau bisa disebut dengan Non Performing Financing (pembiayaan bermasalah), yang dalam hal ini banyak faktor-faktor yang menyebabkan terjadinya pembiayaan bermasalah tersebut.

Walaupun demikian, pembiayaan yang diberikan kepada para nasabah tidak akan lepas dari resiko terjadinya pembiayaan bermasalah yang akhirnya dapat mempengaruhi terhadap kinerja lembaga tersebut. Dalam resiko pembiayaan merupakan risiko yang disebabkan oleh kegagalan counterparty dalam memenuhi kewajiban. ${ }^{2}$ Seorang Account Officer dapat memutuskan apakah suatu permohonan pembiayaan yang diajukan ditolak, diteliti lebih lanjut atau diluluskan. Dengan begitu peranan Account Officer secara tidak langsung dapat mengantisipasi adanya pembiayaan bermasalah. ${ }^{3}$ Dari latar belakang diatas, penulis tertarik untuk menulis penelitian dengan judul "Peran Account Officer dalam Manajemen Pembiayaan di Bank Pembiayaan Rakyat Syariah Daya Artha Mentari Pandaan".

\footnotetext{
${ }^{1}$ Veithzal Rivai , Credit Manajemen Handbook, (Teori, Konsep, Prosedur, dan Aplikasi Panduan Praktik Mahasiswa, Bankir, dan Nasabah), (PT. Raja Grafindo Persada: Jakarta, 2006) hal 293.

2 Adiwarman A. Karim, Bank Islam Analisis Fiqih dan Keuangan, (Jakarta: PT Raja Grafindo Persada,2010), hal: 260

3 Muhammad, Manajemen Pembiayaan Bank Syariah,(Yogyakarta:Akademi Manajemen Perusahaan YKPN, 2005), hal: 59
}

..::: Malia: Jurnal Ekonomi Islam, Volume 10 Nomor 2 Juni 2019 :::.. 
$204\}\{$ Peran Account Officer dalam Manajemen Pembiayaan

\section{KAJIAN TEORI}

1. Pengertian Account Officer

Account Officer adalah aparat manajemen/petugas bank yang ditugaskan untuk membantu direksi dalam menangani tugas-tugas khususnya yang meyangkut bidang marketing dan pembiayaan. Account Officer dituntut memiliki keahlian dan ketrampilan, baik teknis maupun operasional, serta memiliki penguasaan pengetahuan yang bersifat teoritis. Account Officer yang baik telah terbiasa dengan berbagai barang yang lazim digunakan untuk menganalisis, mengetahui cara-cara menganalisis, memiliki pengetahuan yang memadai tentang aspek ekonomi keuangan, manajemen, hukum dan teknis, serta memiliki wawasan yang luas mengenai prinsip-prinsip pembiayaan. Hal ini sesuai dengan firman Allah SWT dalam Al Qur'an, surat An-Nisa' ayat: 135 Sebagai berikut:

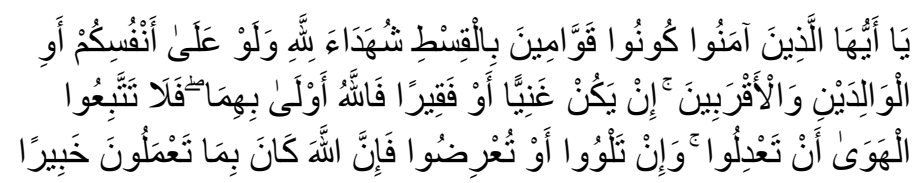

Artinya: Hai orang-orang yang beriman! Jadilah kamu penegak keadilan, menjadi saksi karena Alloh, walaupun terhadap dirimu sendiri atau terhadap ibu bapak dan kaum kerabatmu. Jika dia (yang terdakwa) kaya atau miskin, maka Alloh lebih mengetahui kemaslahatan (kebaikannya). Maka janganlah kamu mengikuti hawa nafsu karena ingin menyimpang dari kebenaran. Dan jika kaти memutarbalikkan (kata-kata) atau enggan menjadi saksi, maka (ketahuilah) sesungguhnya Alloh Mahateliti terhadap segala apa yang kamu kerjakan.(QS An-Nisaa :135). ${ }^{4}$

Di samping itu, Account Officer memiliki fungsi ganda. Di satu pihak ia merupakan personil bank yang harus bekerja di bawah peraturan dan tujuan bank sehingga dapat memberikan hasil kepada bank, dan di pihak lain ia dituntut untuk memberikan kondisi yang paling baik untuk nasabahnya. Oleh karena itu, seorang Account Officer dituntut untuk mengoptimalkan kedua sisi kepentingan tersebut. ${ }^{5}$ Pada dasarnya peran dan fungsi seorang Account Officer adalah:

\footnotetext{
${ }^{4}$ Departemen Agama RI, Al-Qur'an dan Terjemahannya,PT Examedua arkanleema. Hal:144 ${ }^{5}$ Jusuf, Jopie, Panduan dasar untuk Account Officer, (Yogyakarta: Akademi Manajemen Perusahaan YKPN,1997), hal. 8
} 
a. Mengelola Account

Seorang Account Officer berperan untuk membina nasabah agar mendapatkan efisiensi dan optimalisasi dari setiap transaksi keuangan yang dilakukan tanpa meninggalkan tanggung jawabnya sebagai personil bank.

b. Mengelola produk

Seorang Account Officer harus mampu menjembatani kemunngkinan pemakaian berbagai produk sesuai untuk kebutuhan nasabahnya.

c. Mengelola kredit

Account Officer berperan untuk melakukan pemantauan atas pinjaman yang diberikan kepada nasabah agar nasabah selalu memenuhi komitmen atas pinjamannya. Untuk melaksanakan hal ini, seorang AO harus memiliki pengetahuan yang cukup tentang bisnis nasabahnya.

d. Mengelola penjualan

Seorang Account Officer pada dasarnya merupakan ujung tombak bank dalam memasarkan produknya, maka seorang Account Officer juga harus memiliki salesmanship yang memadai untuk dapat memasarkan produk yang ditawarkan.

e. Mengelola profitability

Seorang Account Officer juga berperan dalam menentukan keuntungan yang diperoleh bank. Dengan demikian ia harus yakin bahwa segala hal yang dilakukannya berada dalam suatu kondisi yang memberikan keuntungan kepada bank. ${ }^{6}$

2. Pembiayaan

a. Pengertian Pembiayaan

Pembiayaan merupakan aktivitas dari lembaga keuangan syariah dalam menyalurkan dana kepada pihak lain selain dari lembaga keuangan syariah berdasarkan prinsip syariah. Penyaluran dana dalam bentuk pembiayaan didasarkan pada kepercayaan yang diberikan oleh pemilik dana kepada pengguna dana. ${ }^{7}$

\footnotetext{
${ }^{6}$ Ibid,hal:9

${ }^{7}$ Ismail, Perbankan Syariah, (Jakarta, PT Fajar Pratama Offset, 2011) hal:105-106
} ..::: Malia: Jurnal Ekonomi Islam, Volume 10 Nomor 2 Juni 2019 :::... 
Menurut UU No.7 tahun 1992 tentang perbankan sebagaimana telah diubah menjadi UU No.10 tahun 1998 tentang Perbankan dalam Pasal 1 nomor (13): "Prinsip syariah adalah aturan perjanjian berdasarkan hukum Islam antara bank dan pihak lain untuk penyimpanan dana atau pembiayaan kegiatan usaha, atau kegiatan lainnya yang dinyatakan sesuai dengan syariah, antara lain pembiayaan berdasarkan prinsip bagi hasil (mudharabah), pembiayaan berdasarkan prinsip penyertaan modal (musyarakah), prinsip jual beli barang dengan memperoleh keuntungan (murabahah), atau pembiayaan barang modal berdasarkan prinsip sewa murni tanpa pilihan (ijarah), atau dengan adanya pilihan pemindahan kepemilikan atas barang yang disewa dari pihak bank oleh pihak lain (ijarah wa iqtina). ${ }^{8}$

b. Tujuan Pembiayaan

Secara umum tujuan pembiayaan dibedakan menjadi dua kelompok yaitu: tujuan pembiayaan untuk tingkat makro dan tujuan pembiayaan untuk tingkat mikro. Secara makro dijelaskan bahwa pembiayaan bertujuan:

1) Peningkatan ekonomi umat, artinya: masyarakat yang tidak dapat akses secara ekonomi, dengan adanya pembiayaan mereka dapat melakukan akses ekonomi.

2) Tersedianya dana bagi peningkatan usaha, artinya untuk pengembangan usaha membutuhkan dana tambahan. Pihak yang surplus dana menyalurkan kepada pihak yang minus dana, sehingga dapat di gulirkan.

3) Meningkatkan produktivitas, artinya adanya pembiayaan memberikan peluang bagi masyarakat agar mampu meningkatkan daya produksinya.

4) Membuka lapangan kerja baru, artinya dengan dibukanya sektorsektor usaha melalui penambahan dana pembiayaan, maka sektor usaha tersebut akan menyerap tenaga kerja.

5) Terjadinya distribusi pendapatan, artinya masyarakat usaha produktif mampu melakukan aktivitas kerja, berarti mereka akan memperoleh pendapatan dari hasil usahanya.

\footnotetext{
${ }^{8}$ www.bi.go.id/id/tentang-bi/uu-bi/Documents/uu_bi_1099.pdf undang-undang republik indonesia nomor 7 tahun 1992 tentang perbankan sebagaimana telah diubah dengan undang-undang nomor 10 tahun 1998 di akses pada 27 Desember 2017 jam 18:22.
}

..::: Malia: Jurnal Ekonomi Islam, Volume 10 Nomor 2 Juni 2019 :::... 
c. Fungsi Pembiayaan.

Pembiayaan mempunyai peranan sangat penting dalam perekonomian. Secara garis besar fungsi pembiayaan didalam perekonomian, perdagangan dan keuangan dapat dikemukakan sebagai berikut:

1) Pembiayaan dapat meningkatkan utility (daya guna) dari modal/uang.

2) Pembiayaan peningkatan utility suatu barang.

3) Pembiayaan meningkatkan peredaran dan lalu lintas uang.

4) Pembiayaan dapat mengaktifkan dan meningkatkan manfaat ekonomi yang ada.

5) Stabilitas ekonomi.

6) Pembiayaan sebagai jembatan untuk peningkatkan pendapatan.

7) Sebagai alat hubungan ekonomi Internasional. ${ }^{9}$

d. Pembiayaan Bermasalah

Pembiayaan bermasalah adalah suatu keadaan dimana seorang nasabah tidak mampu membayar lunas pembiayaan pada bank dengan tepat waktu. Pada kenyataannya selalu ada nasabah yang tidak dapat mengembalikan pembiayaannya kepada bank yang telah meminjamkannya, maka hal tersebut dapat menjadikan perjalanan pembiayaan terhenti dan bermasalah. ${ }^{10}$

Risiko pembiayaan bermasalah dapat diperkecil dengan melakukan analisa pembiayaan, yang tujuan utamanya adalah menilai seberapa besar kemampuan dan kesediaan debitur mengembalikan pembiayaan yang mereka pinjam dan membayar margin keuntungan dan bagi hasil sesuai dengan isi perjanjian pembiayaan. Dengan begitu peranan Account Officer secara tidak langsung dapat mengantisipasi adanya pembiayaan bermasalah. ${ }^{11}$

Ketidaklancaran nasabah dalam membayarkan angsuran pokok maupun bagi hasilnya menyebabkan adanya kolektabilitas pembiayaan, secara umum kolektabilitas pembiayaan dikategorikan menjadi lima macam:

\footnotetext{
${ }^{9}$ Rivai, dan Reitshal, Islamic Financial Management,... hal: 8. Lihat juga pada Muhammad, Manajemen Dana Bank Syariah, (Yogyakarta: Ekonosia: 2004), hal:197-199

${ }^{10}$ Gatot Supramono, Perbankan dan Masalah Kredit: Suatu Tinjauan Yuridis, (Jakarta: Djambatan, 1996), hal:131

${ }^{11}$ Muhammad, Manajemen Pembiayaan Bank Syariah...Hal:59
} ..::: Malia: Jurnal Ekonomi Islam, Volume 10 Nomor 2 Juni 2019 :::... 
1) Kolektibilitas kosong atau disebut dengan kredit lancar, artinya segala kewajiban (angsuran utang pokok atau marginnya dapat diselesaikan oleh nasabah dengan baik).

2) Kolektibilitas 1 (satu) atau disebut dengan kredit kurang lancar, artinya kredit yang selama 3 atau 6

3) Bulan mutasinya tidak lancar, pembayaran margin atau utang pokoknya tidak baik dalam artian pembayarannya lancar tapi terdapat tunggakan.

4) Kolektibilitas 2 (dua) atau disebut dengan kredit diragukan, artinya kredit yang telah tidak lancar dan

5) Telah pada jatuh temponya belum dapat juga diselesaikan oleh debitur yang bersangkutan. Digolongkan diragukan apabila pembiayaan yang bersangkutan tidak memenuhi kriteria lancar dan kurang lancar.

6) Kolektibitas 3 (tiga) atau disebut dengan kredit menuju macet, artinya seorang nasabah atau debitur sudah kurang mampu dalam pembayaran, yang mana seorang debitur sudah terlalu banyak tunggakan pembayaran margin dan utang pokoknya.

7) Kolektibilitas macet (kredit macet), artinya seorang nasabah sudah tidak memenuhi kriteria lancar, kurang lancar dan diragukan, memenuhi kriteria menuju macet tetapi jangka waktu 21 bulan sejak digolongkan diragukan belum ada pelunasan atau usaha penyelamatan. Pembiayaan tersebut penyelesaiannya telah diserahkan kepada pengadilan negeri atau badan urusan piutang negara (BUPN) atau diajukan penggantian rugi kepada perusahaan asuransi kredit atau di badan Arbitrase Syariah. ${ }^{12}$

e. Mencegah timbulnya Kredit Macet

Sama seperti penyakit lainnya, pada perbankan juga berlaku nasehat"lebih baik mencegah dari pada mengobati" banyak tenaga, biaya dan perhatian yang harus dikeluarkan untuk menyelesaikan sebuah pembiayaaan bermasalah. Tindakan pertama yang bisa dilakukan untuk mencegah terjadinya sebuah pembiayaan bermasalah adalah berhati-hati dalam memberikan pembiayaan. Seorang Account Officer harus bertindak konservatif dalam menyalurkan pembiayaan.

12 Nur Lailatus Sya'adah. Wawancara. dengan Pak Fajar Selaku Account Officer diBPRS Daya Artha Mentari Pandaan, Pada Rabu, 24 Januari 2018, Pukul 10. 46 WIB

..::: Malia: Jurnal Ekonomi Islam, Volume 10 Nomor 2 Juni 2019 :::.. 
Dalam mengantisipasi masa depan, jangan hanya berprediksi dari sudut optimis, yakni usaha Mudharib berkembang dengan baik dan maju, tetapi juga harus dari estimasi yang pesimis atau konservatif. Tentu saja tidak ada yang berharap skenario gagalnya usaha Mudharib terjadi, tetapi seorang Account Officer harus bertanya bahwa seandainya hal tersebut terjadi, bagaimana posisi bank sebagai Shahibul maal. Tindakan lain dalam mencegah timbulnya pembiayaan bermasalah adalah dengan pengawasan pembiayaan secara terus menerus. ${ }^{13}$

Karena sesungguhnya risiko pembiayaan baru saja dimulai ketika pencairan dilakukan, pengawasan dapat dilakukan dengan memantau realisasi pencapaian target usaha dengan cara memantau melalui menyelediki dengan cara bertanya-tanya kepada seorang yang ada di sekitar usahanya, apakah seorang yang meminjam pembiayaan tersebut usahanya berjalan lancar atau macet. ${ }^{14}$ Karena tidak semua nasabah memiliki karakter bisnis yang sama satu sama lainnya. Dalam kenyataanya ada nasabah yang sukses dalam mengelola bisnis namun ada pula yang gagal. ${ }^{15}$

Apabila terjadi tidak tercapainya target maka pihak bank harus segera melakukan tindakan penyelamatan. Tindakan penyelamatan awal adalah dengan langsung turun ke lapangan menemui nasabah untuk mengetahui permasalahan utama yang dialami oleh nasabah dengan cara kekeluargaan dan apabila seorang nasabah merasa keberatan dan ada kendala dalam mengangsur pembiayaan maka seorang Account Officer dapat memberikan suatu solusi yang terbaik dan mengurangi biaya angsuran dan memperkecil margin keuntungan seorang nasabah agar sedikit ringan dalam pembayaran. ${ }^{16}$

f. Penanganan Pembiayaan Bermasalah

Banyak cara yang dapat dilakukan bank untuk menyelesaikan pembiayaan bermasalah, tergantung pada berat ringannya

\footnotetext{
13 Jopie Jusuf, Panduan dasar Untuk Account Officer...hal: 202-204

${ }^{14}$ Nur lailatus sya'adah, wawancara. Wawancara. dengan Pak Fajar Selaku Account Officer di BPRS Daya Artha Mentari Pandaan, Pada Rabu, 24 Januari 2018, Pukul 10. 46 WIB

${ }^{15}$ Muhammad, Manajemen Pembiayaan Bank Syariah..hal:163. Lihat juga Sunarto Zulkifli, Panduan Praktis Transaksi Perbankan Syariah..hal:155

${ }^{16}$ Nur Lailatus Sya'adah. Wawancara Wawancara. dengan Pak Fajar Selaku Account Officer diBPRS Daya Artha Mentari Pandaan, Pada Rabu, 24 Januari 2018, Pukul 10. 46 WIB
} 
permasalahan yang dihadapi, serta sebab-sebab terjadinya kemacetan. Apabila pembiayaan itu masih dapat diharapkan akan berjalan baik kembali, maka bank dapat memberikan keringanan-keringanan, misalnya menunda jadwal angsuran (rescheduling). Untuk keperluan penghapusan itu bank diharuskan untuk membentuk cadangan penyisihan penghapusan aktiva produktif (PPAP), sebagai berikut:

1) Bank wajib membentuk cadangan $1 \%$ dari seluruh pembiayaan.

2) Cadangan 3\% dari pembiayaan yang tergolong tidak lancar (setelah dikurangi nilai agunan yang telah dikuasai)

3) Cadangan 50\% dari pembiayaan yang tergolong diragukan (setelah dikurangi nilai agunan yang dikuasai).

4) Cadangan $100 \%$ dari pembiayaan yang tergolong macet (setelah dikurangi nilai agunan yang dikuasai).

\section{METODE}

\section{Metode Observasi}

Observasi adalah pengamatan terhadap suatu obyek yang diteliti baik secara langsung maupun tidak langsung untuk memperoleh data yang harus di kumpulkan dalam penelitian. Secara langsung adalah terjun ke lapangan dan melibatkan seluruh pancaindera. ${ }^{17}$ Observasi ini merupakan pengumpulan-pengumpulan data dengan cara melakukan pencatatan dan pengamatan langsung terhadap objek tertentu dilapangan, dalam observasi nampaknya hanya sekedar mengamati namun kegiatan mengamati ini tidak boleh di pandang main-main oleh peneliti. Dalam hal ini peneliti melakukan observasi pengamatan untuk mengetahui suasana kerja di BPRS Daya Artha Mentari serta mencatat segala hal yang berhubungan dengan pembiayaan, proses pembiayaan dan penyelesaian pembiayaan bermasalah.

2. Wawancara (Interview)

Secara konseptual wawancara merupakan sebuah percakapan antara dua orang atau lebih yang pertanyaan diajukan oleh peneliti pada subjek atau informan, sumber atau responden penelitian untuk mendapatkan jawaban. ${ }^{18}$ Dalam teknik wawancara ini peneliti bisa

${ }^{17}$ Ismail Nawawi, Metode Penelitian Kualitatif: Teori dan Aplikasi Interdisipliner Untuk Ilmu Sosial, Ekonomi/Ekonomi Islam, Agama, Manajemen, dan Ilmu Sosial lainnya, (Jakarta: CV. Dwiputra Pustaka Jaya, 2012), hal: 186

${ }^{18}$ Ibid, hal: 203

..:::: Malia: Jurnal Ekonomi Islam, Volume 10 Nomor 2 Juni 2019 :::... 
mendapatkan semua data-data yang di perlukan dengan cara melakukan tanya jawab atau face to face dengan para informan sehingga mendapatkan semua informasi dengan tepat dan jelas serta akurat. Dalam hal ini peneliti memperoleh informasi yang berkenaan dengan hal-hal yang berkaitan dengan data-data tentang proses kerja manajemen dan Account Officer terhadap permohonan pembiayaan dan tentang resiko dalam pembiayaan bermasalah yang terjadi di BPRS Daya Artha Mentari Cabang Pandaan. Wawancara ini telah dilakukan dengan beberapa pihak:

a. Pihak manajemen BPRS Daya Artha Mentari, tujuannya untuk mendapatkan data-data secara langsung seputar profil lembaga dan proses pembiayaan yang ada di BPRS Daya Artha Mentari.

b. Pihak pembiayaan BPRS Daya Artha Mentari, dalam wawancara ini penulis memperoleh informasi tentang tugas dan tanggung jawab manajemen pembiayaan yang ada serta tanggung jawab seorang Account Officer.

Adapun beberapa pertanyaan yang diajukan penulis sebagai berikut:

a. Bagaimana proses pembiayaan yang ada di BPRS Daya Artha Mentari?

b. Apa saja persyaratan yang harus di lengkapi oleh nasabah dalam pembiayaan?

c. Bagaimana langkah pihak BPRS Daya Artha Mentari dalam menangani pembiayaan bermasalah?

3. Metode Dokumentasi

Dokumentasi adalah pengumpulan data dengan meneliti catatancatatan penting yang sangat erat hubungannya dengan objek penelitian. Dokumentasi diperoleh dengan cara mencari data mengenai hal-hal atau variable yang berupa catatan, transkrip, buku, surat kabar, majalah, notulen rapat, agenda dan sebagainya. ${ }^{19}$ Tujuan dari penggunaan metode ini yaitu untuk memperoleh data yang kongkrit mengenai penerapan pembiayaan di BPRS Daya Artha Mentari.

19 Soeranto dan Licolin Arsyad, Metodologi Penelitian: Untuk Ekonomi dan Bisnis,(Yogyakarta: UPP AMP YKPN,2003),hal.89

..::: Malia: Jurnal Ekonomi Islam, Volume 10 Nomor 2 Juni 2019 :::.. 


\section{PEMBAHASAN HASIL}

1. Peran Account Officer dalam Manajemen Pembiayaan

Produk pembiayaan yang ada di BPRS Daya Artha Mentari meliputi pembiayaan musyarakah, mudharabah, ijarah, wakalah dan murabahah. Produk pembiayaan yang ada di BPRS Daya Artha Mentari Pandaan merupakan suatu kegiatan penyaluran dana kepada masyarakat yang membutuhkan untuk kepentingan pribadinya dalam mensejahterakan keluarganya dan sebagai bentuk tujuan lembaga keuangan dalam memaksimalkan laba, dalam hal ini pemberian pembiayaan didasarkan atas kepercayaan yang digunakan dengan benar, adil dan harus disertai dengan syarat-syarat yang jelas dan sesuai dengan prisip syariah. Dalam pembagiannya menggunakan prinsip bagi hasil. Proses pembiayaan yang baik adalah proses pembiayaan yang mampu menghasilkan keuntungan sesuai dengan yang kita harapkan, dalam hal pembiayaan proses awal yang terjadi pada lembaga keuangan umumnya adalah dimulai dari proses permohonan pembiayaan, sama halnya dengan yang terjadi di BPRS Daya Artha Mentari. Adapun tahapantahapan itu adalah sebagai berikut:

a. Permohonan pembiayaan

Tahap awal dari proses pembiayaan di BPRS Daya Artha Mentari adalah pengajuan permohonan pembiayaan. Permohonan pembiayaan dapat dilakukan secara tertulis maupun lisan. Inisiatif pengajuan pembiayaan biasanya datang dari nasabah yang kekurangan modal atau membutuhkan modal tambahan untuk pengembangan usahanya atau untuk membuka usaha baru. Dari tahap permohonan ini calon nasabah di BPRS Daya Artha Mentari Pandaan langsung diserahkan kepada pihak Account Officer, Account Officer di BPRS Daya Artha Mentari ini berperan dalam memanajemen pembiayaan yaitu dari awal pengajuan dana, pencairan, pengawasan dan penyelesaian pembiayaan. Ketika awal calon nasabah mengajukan pembiayaan akan ditanya butuh dana berapa, untuk apa, dan usaha apa yang akan dilakukan setelah itu akan diberi memo yang berisikan tentang identitas calon nasabah serta keperluan dana yang diajukan dan untuk tahap selanjutnya mengumpulkan syarat-syarat yang harus dipenuhi agar pembiayaan dapat ditindak lanjuti. Adapun semua syarat-syarat yang harus dipenuhi adalah sebagai berikut: 
1) KTP Suami Istri, data identitas nasabah diperlukan untuk mengetahui legalitas pribadi serta alamat tinggal calon nasabah. Hal ini terkait dengan alamat penagihan dan penyelesaian masalah-masalah tertentu dikemudian hari untuk keterangan suami/istri disini bertujuan untuk menghindari kasus seseorang pasangan suami/istri tidak tahu bahwa pasangannya terlibat hutang di BPRS Daya Artha Mentari.

2) Foto copy KK, surat nikah untuk nasabah yang menggunakan saksi suami/istri hal ini diperlukan untuk mengetahui jumlah tanggungan keluarga, dan untuk mengetahui kebenaran ikatan perkawinan keduanya.

3) Jaminan, jaminan disini bisa berupa BPKB atau sertifikat SHM (Surat Hak Milik). Hal ini bertujuan sebagai ikatan atas biaya yang diberikan dan menambah kehati-hatian nasabah dalam menjalankan usahanya dan mengganggapnya sebagai amanat yang harus disampaikan. Jaminan ini dilengkapi dengan Foto Copy BPKB, Foto Copy sertifikat SHM. Foto copy jaminan diperlukan untuk mengetahui kebenaran jaminan, nilai jaminan dan status jaminan.

b. Survey

Apabila tahap permohonan sudah memenuhi persyaratan administrasi, maka dapat diteruskan dengan pengumpulan dana dan survey, namun apabila permohonan pembiayaan ditolak, maka penolakan dilakukan tanpa menunda-nunda waktu. Penolakan dapat dilakukan baik dari segi tulis maupun lisan untuk efisiensi waktu. Dalam proses ini di BPRS Daya Artha Mentari ini menggunakan analisis 5C yaitu:

1) Character, untuk menetukan apakah orang ini layak atau tidak diberikan pembiayaan dapat dilihat dari tanggung jawab seseorang, kejujurannya dan keseriusannya. Hal-hal tersebut dapat kita peroleh dengan cara berkomunikasi, bagaimana cara dia bersosialisasi, informasi tersebut bisa kita peroleh dari rekan kerja, saudara dan juga tetangganya. Kita juga bisa mendapatkan informasi tambahan dari Account Officer lainnya.

2) Capacity, yaitu kemampuan nasabah untuk menjalankan usahanya, kemampuan yang dimiliki nasabah untuk membuat rencana dan merealisasikan rencana tersebut menjadi kenyataan, 
termasuk dalam menjalankan usahanya agar memperoleh laba sesuai yang diharapkan. Penilaian kemampuan calon nasabah meliputi: kemampuan bidang manajemen, keuangan, pemasaran dan teknis. Dalam hal ini kita melakukan kunjungan langsung ke tempat usahanya dengan melihat secara langsung atau mencari informasi dengan orang yang dekat dengan usahanya.

3) Capital. Penilaian terhadap capital dimaksudkan untuk mengetahui keadaan permodalan, sumber modal, dan penggunaan sehingga dapat diketahui berapa jumlah biaya yang harus diberikan. Untuk hal ini Account Officer yang melakukan survey mencocokkan tentang kondisi yang ada di lapangan dengan yang telah dijelaskan kepada pihak BPRS Daya Artha Mentari.

4) Collateral, penilaian jaminan dilihat dari segi ekonomisnya, penyusutan dan harga pasarannya, jaminan yang digunakan di BPRS Daya Arta Mentari ini berupa BPKB motor untuk pembiayaan kecil dibawah lima juta rupiah dan sertifikat tanah untuk pembiayaan besar lima belas juta keatas, dengan demikian seorang Account Officer harus selalu update tentang harga pasaran motor dan tanah. Karena hal tersebut akan memudahkan dalam bekerja.

5) Condition, condition adalah sosial ekonomi sekarang dan yang akan datang yang dapat mempengaruhi maju mundurnya usaha calon nasabah. Setelah dilakukan survey selanjutnya Account Officer akan memberikan keputusan apakah pengajuan tersebut layak direalisasikan atau tidak, jika memang tidak layak maka pihak Account Officer secepatnya akan memberitahu kepada nasabah, begitu juga sebaliknya. Dan jika pengajuan tersebut disetujui maka Account Officer akan mengajukan kepada pimpinan dan tahap selanjutnya adalah pencairan.

c. Realisasi pembiayaan Sebelum melakukan pencairan pihak BPRS akan mengecek ulang tentang kelengkapan dokumen calon nasabah, jika memang semuanya sudah lengkap maka selanjutnya adalah penandatanganan akad yang dilakukan oleh nasabah dan juga saksi. Akad pembiayaan berisi tentang:

1) No Register yang berguna sebagai data pembayaran angsuran nasabah.

2) Tanggal penandatanganan akad

..::: Malia: Jurnal Ekonomi Islam, Volume 10 Nomor 2 Juni 2019 :::... 
3) Nama Nasabah dan saksi

4) Jumlah pinjaman

5) Jangka waktu angsuran

6) Presentase keuntungan

7) Nilai angsuran

8) Keterangan jaminanan.

d. Setelah selesai penandatanganan akad nasabah dibuatkan kartu angsuran yang akan digunakan setiap bulannya, untuk memantau angsuran yang telah dibayarkan.

e. Monitoring, yang dilakukan untuk mencegah risiko pembiayaan bermasalah adalah dengan sering melakukan kunjungan ke rumah atau ke tempat kerja nasabah. Dalam melakukan analisis seorang Account Officer harus selalu menjunjung tinggi nilai profesionalisme dalam tindakannya. Seorang Account Officer juga harus memiliki prinsip sendiri berdasarkan analisis yang dilakukannya. Seorang Account Officer harus tegas dalam mengambil suatu keputusan, jangan segansegan menolak sebuah pembiayaan jika dari hasil analisis memang tidak layak untuk di biayai oleh bank. Kelengkapan dokumentasi sebelum pembiayaan di realisasi. Seorang Account Officer harus menyadari bahwa tidak semua keinginan nasabah dapat dan harus dipenuhi oleh bank. Seorang Account Officer harus selalu memelihara posisi sebagai penghubung antara bank dengan nasabah, dan pada titik terakhir, ia harus selalu menempatkan bank sebagai prioritas utama. Karena kesuksesan pembiayaan dalam dunia perbankan ada di tangan seorang Account Officer. Di BPRS Daya Artha Mentari Pandaan mempunyai 3 orang Account Officer diantaranya ada Bapak Zainul Arifin, S.E, Bapak Fajar dan Bapak Fauzi.

2. Strategi Account Officer dalam mencegah resiko pembiayaan bermasalah

Sesungguhnya risiko pembiayaan baru saja dimulai ketika pencairan dilakukan, pengawasan dapat dilakukan dengan memantau realisasi pencapaian target usaha, apabila pembiayaan terindikasi bermasalah tindakan pertama yang bisa dilakukan untuk mencegah terjadinya sebuah pembiayaan bermasalah adalah berhati-hati dalam memberikan pembiayaan. Ada dua hal yang dapat dilakukan dalam proses penanganan pembiayaan bermasalah di antaranya adalah:

a. Analisis dalam penyelesaian pembiayaan bermasalah. 
$216\}\{$ Peran Account Officer dalam Manajemen Pembiayaan

Ketika nasabah tidak mampu lagi untuk membayarkan angsuranyang telah dibebankan dari pembiayaan yang dilakukan maka untuk mengantisipasi hal tersebut pihak BPRS akan melakukan analisis.

1) Analisis faktor internal

Faktor yang ada dalam perusahaan tersebut, dan faktor utama yang paling dominan adalah faktor manajerial. Timbulnya kesulitan-kesulitan keuangan perusahaan yang disebabkan oleh faktor manajerial dapat dilihat dari beberapa hal seperti lemahnya pengawasan biaya dan pengeluaran, kebijakan piutang yang kurang tepat, penempatan yang berlebihan pada aktiva tetap dan permodalan yang tidak cukup.

2) Petugas (Account Officer)

a) Kurangnya analisis yang dilakukan dalam pemberian pembiayaan

b) Lemahnya sistem informasi pembiayaan serta sistem pengawasan administrasi pembiayaan mereka.

c) Pengikatan jaminan yang kurang sempurna.

b. Analisis faktor eksternal

Faktor eksternal berada diluar kekuasaan manajemen seperti terjadinya bencana alam, kecelakaan, inflasi dll.

1) Nasabah

2) Character nasabah mengalami kecelakaan

3) Kapasitas ketidakmampuan nasabah dalam mengelola usahanya.

4) Lingkungan

5) Ketidakmampuan nasabah dalam melakukan persaingan bisnis

Banyak cara yang dapat dilakukan oleh BPRS untuk penyelesaian pembiayaan bermasalah ini, tergantung pada berat ringannya masalah yang dihadapi serta sebab-sebab terjadinya pembiayaan bermasalah. Pengawasan terhadap pembiayaan juga dilakukan dalam meminimalisir terjadinya pembiayaan bermasalah, pengawasan yang dilakukan oleh pihak BPRS Daya Artha Mentari Pandaan adalah dengan melakukan kunjungan ke tempat usaha nasabah, dengan melihat dan bertanya dengan kondisi usahanya. Pengawasan juga dilakukan dengan melihat rekening nasabah yang bersangkutan untuk memastikan bahwa pembiayaan yang dilakukan masih tetap lancar atau tidak. Penyelesaian pembiayaan bermasalah 
dilakukan sesuai dengan kolektabilitasnya. Adapun beberapa langkah yang dilakukan oleh pihak BPRS Daya Artha Mentari adalah sebgai berikut:

1) Memberikan somasi kepada nasabah ketika sudah menunggak selama tiga bulan dan somasi selanjutnya akan diberikan bulan berikutnya ketika nasabah tetap tidak membayarkan tunggakannya, Somasi diberikan sampai tiga kali dan yang ketiga dengan keterangan pengamanan barang jaminan.

2) Melakukan rescheduling yaitu penjadwalan kembali jangka waktu angsuran, ketika nasabah sudah benar-benar dalam kesulitan dan masih ada i'tikad baik untuk menyelesaikan pembiayaannya maka solusi yang ditawarkan oleh BPRS Daya Artha Mentari adalah dengan memperpanjang lama angsuran pembiayaan. Adapun yang mengalami perubahan adalah: a) Jangka waktu pembiayaan. b) Jadwal angsuran. c) Jumlah angsuran.

3) Melakukan reconditioning yaitu memperkecil margin keuntungan nisbah bagi hasil. Ketika nasabah merasa tidak mampu dengan tingkat bagi hasil yang selama ini diberikan dan akhirnya pembiayaan terindikasi bermasalah, maka bisa melakukan reconditioning. Penyitaan barang jaminan sebenarnya penyitaan barang jaminan adalah hal yang sangat dihindari oleh pihak BPRS Daya Artha Mentari namun ketika nasabah tidak ada i'tikad baik untuk menyelesaikan pembiayaan maka hal tersebut harus dilakukan, karena dana BPRS Daya Artha Mentari ada dana milik umat yang harus dipertanggung jawabkan kembali. Penyitaan jaminan dilakukan dengan cara yang baik, sopan, ketika surat somasi yang ketiga telah diberikan kepada nasabah yang berisikan tentang pengamanan barang jaminan dan ketika sampai pada somasi ketiga tetap tidak ada respon maka proses selanjutnya pihak BPRS Daya Artha Mentari akan melakukan pengamanan jaminan sebagaimana telah tercantum pada akad, dengan catatan dalam melakukan penyitaan harus disetujui oleh pemilik barang. Penjual barang jaminan dilakukan ketika sudah jatuh tempo atau sesuai dengan kesepakatan, atau penjualan dapat dilakukan sebelum jatuh tempo dengan kesepakatan antara dua belah pihak. Jika barang berupa tanah maka pihak BPRS Daya Artha Mentari akan melakukannya penjualan melalaui balai lelang. Setelah 
$218\}\{$ Peran Account Officer dalam Manajemen Pembiayaan

melakukan lelang maka akan keluar risalah lelang yang digunakan untuk membalik nama.

\section{KESIMPULAN}

Berdasarkan hasil penelitian di PT. BPRS Daya Artha Mentari Pandaan, penulis dapat menyimpulkan beberapa hal yang berhubungan dengan hasil penelitian yang sudah penulis paparkan tentang "Peran Account Officer Dalam Manajemen Pembiayaan Di Bank Pembiayaan Rakyat Syariah Daya Artha Mentari Pandaan". Ada dua hal yang bisa disimpulkan yaitu:

1. Peran Account Officer dalam manajemen pembiayaan di BPRS Daya Artha Mentari sebagai berikut:

a. Proses pembiayaan yang terjadi di PT. BPRS Daya Artha Mentari Pandaan dimulai dari pengajuan, mengisi memo pembiayaan, menyerahkan persyaratan lengkap (berupa jaminan BPKB, foto copy jaminan $\mathrm{BPKB}$, foto copy $\mathrm{KK}$, foto copy surat nikah , foto copy STNK, foto copy surat sertifikat SHM) selanjutnya survey oleh Account Officer, diajukan ke pimpinan, dan yang terakhir adalah pencairan.

b. Survey yang dilakukan menggunakan analisis 5C yaitu: Character adalah aspek yang paling penting dan paling utama untuk diperhatikan yaitu berupa sifat dan karakter calon nasabah. Untuk Capacity dilihat dari keadaan usaha nasabah sedangkan untuk Capital dilihat dari penghasilan dan kemampuan bayar dari nasabah. Conditonal hanya di sesuaikan yang terakhir adalah Collateral hal ini juga aspek yang sangat penting, karena jaminan adalah satu-satunya penyelamat pembiayaan macet.

c. Pengawasan dilakukan untuk pengamanan pembiayaan yang diberikan kepada nasabah, dengan cara memantau rekening nasabah dan sering melakukan kunjungan ke rumah nasabah.

2. Strategi Account Officer untuk mengatasi resiko pembiayaan bermasalah

Dari hasil penelitian yang dilakukan penulis di PT. BPRS Daya Artha Mentari Pandaan tentang strategi Account Officer dalam mengatasi pembiayaan bermasalah adalah sebagai berikut:

a. Melakukan rescheduling yaitu penjadwalan kembali jangka waktu angsuran serta memperkecil jumlah angsuran.

b. Memberikan somasi ketika nasabah sudah 3 bulan tidak membayar angsuran, somasi akan diberikan sampai 3 bulan selanjutnya.

..::: Malia: Jurnal Ekonomi Islam, Volume 10 Nomor 2 Juni 2019 :::... 
c. Penarikan jaminan sebagaimana telah tercantum pada akad.

Berdasarkan dari hasil penelitian yang penulis lakukan di PT BPRS Daya Artha Mentari Pandaan, maka penulis memberikan beberapa rekomendasi berikut:

a. Lebih giat dalam melakukan promosi dan penyebaran brosur kepada masyarakat tentang produk yang dimiliki oleh PT BPRS Daya Artha Mentari agar masyarakat bisa merasakan kepuasaan dan kepercayaan yang mendalam kepada BPRS Daya Artha Mentari, sehingga dapat membantu lembaga dalam memaksimumkan profitnya dan dapat meningkatkan kegiatan usaha masyarakat melalui pembiayaanpembiayaan yang sudah tersedia.

b. Peningkatan kinerja lembaga yang handal dan profesional agar sebuah lembaga mampu bersaing dengan lembaga keuangan lainnya.

c. Untuk lembaga agar meringankan persyaratan- persyaratan untuk nasabah yang akan melakukan pembiayaan, jika sebuah pembiayaannya kecil maka tanpa adanya agunan sedangkan kalau pembiayaannya besar dengan menggunakan agunan, sehingga dapat melancarkan lembaga dalam mencapai kesejahteraan perusahaan.

\section{DAFTAR PUSTAKA}

A Karim, Adiwarman. 2010. Bank Islam Analisis Fiqih dan Keuangan. Jakarta: PT Raja Grafindo Persada.

Ade dan Edia. 2006. Bank dan lembaga keuangan bukan Bank. Jakarta: PT INDEKS.

Antonio, Muhammad Syafi'i. 2001. Bank Syariah: Dari Teori ke Praktik. Jakarta: Gema Insani Press.

Departemen Agama RI, Al-Qur'an dan Terjemahannya, PT Examedua arkanleema.

Dokumen, PT BPRS Daya Artha Mentari.

Ismail. 2011. Perbankan Syariah. Jakarta: PT Fajar Pratama Offset.

Ismail. 2011. Perbankan Syariah. Jakarta: Kencana.

Jusuf, Jopie.1997. Panduan dasar untuk Account Officer. Yogyakarta: Akademi Manajemen Perusahaan YKPN.

Muhammad. 2004. Manajemen Dana Bank Syariah. Yogyakarta: Ekonosia.

Muhammad. 2005. Manajemen Pembiayaan Bank Syariah. Yogyakarta: Akademi Manajemen Perusahaan YKPN. 
$220\}\{$ Peran Account Officer dalam Manajemen Pembiayaan

Nawawi, Ismail. 2012. Fikih Muamalah Klasik dan Kontemporer. Bogor: Ghalia Indonesia.

Nawawi, Ismail. 2012. Metode Penelitian Kualitatif: Teori dan Aplikasi Interdisipliner Untuk Ilmu Sosial, Ekonomi/Ekonomi Islam, Agama, Manajemen, dan Ilmu Sosial lainnya. Jakarta: CV. Dwiputra Pustaka Jaya.

Nur Asiyah, Binti. 2014.Manajemen Pembiayaan Bank Syariah. Yogyakarta: Teras.

Nur Lailatus Sya'adah, Wawancara. dengan Pak Fajar Selaku Account Officer di BPRS Daya Artha Mentari Pandaan, Pada Rabu, 24 Januari 2018, Pukul 10. 46 WIB

Soeranto dan Licolin Arsyad. 2003. Metodologi Penelitian: Untuk Ekonomi dan Bisnis. Yogyakarta: UPP AMP YKPN.

Suparmono, Gatot. Perbankan dan Masalah Kredit: Suatu Tinjauan Yuridis. Jakarta: Djambatan.

Tim Penyusun, Sejarah PT.BPRS Daya Artha Mentari.

Veithzal, Rivai.2006. Credit Manajemen Handbook, (Teori, Konsep, Prosedur, dan Aplikasi Panduan Praktik Mahasiswa, Bankir, dan Nasabah. Jakarta : PT. Raja Grafindo Persada.

Wawancara dengan Mbak Intan Erlina Selaku Accounting dan Laporan BPRS Daya Artha Mentari Bangil, Pada Rabu, 10 Januari 2018, Pukul 10. 46 WIB

www.bi.go.id/id/tentang-bi/uu-bi/Documents/uu_bi_1099.pdf undang undang republik indonesia nomor 7 tahun 1992 tentang perbankan sebagaimana telah diubah dengan undang-undang nomor 10 tahun 1998 di akses pada tanggal 27 Desember 2017 jam 18:22.

Zulkifli, Sunarto Zulkifli. 2003.Panduan Praktis Transaksi Perbankan Syariah. Jakarta: Zikrul Hakim. 